\title{
Correction to: Malaxideae (Orchidaceae) in Madagascar, the Mascarenes, Seychelles and Comoro Islands
}

\author{
Johan Hermans ${ }^{1,2}$, Simon Verlynde ${ }^{3}$, Phillip Cribb ${ }^{1}$, Brigitte Ramandimbisoa ${ }^{4}$, Jean-Michel Hervouet ${ }^{5}$ \\ \& Patrice Bernet ${ }^{6}$
}

\author{
Correction to: KEW BULLETIN (2020) 75:1 \\ https://doi.org/10.1007/S12225-019-9851-0
}

The original version of this article unfortunately contains an error. Figure 6 on page 28 and Figure 64 on page 140 were missing from the published version of the paper.

The original article has been corrected.

Open Access This article is licensed under a Creative Commons Attribution 4.0 International License, which permits use, sharing, adaptation, distribution and reproduction in any medium or format, as long as you give appropriate credit to the original author(s) and the source, provide a link to the Creative Commons licence, and indicate if changes were made. The images or other third party material in this article are included in the article's Creative Commons licence, unless indicated otherwise in a credit line to the material. If material is not included in the article's Creative Commons licence and your intended use is not permitted by statutory regulation or exceeds the permitted use, you will need to obtain permission directly from the copyright holder. To view a copy of this licence, visit http:// creativecommons.org/licenses/by/4.0/.

\section{Publisher's Note}

Springer Nature remains neutral with regard to jurisdictional claims in published maps and institutional affiliations.

2 Core Facility, Botanical Garden, University of Vienna, Rennweg 14, 1030, Vienna, Austria.

3 Missouri Botanical Garden (MBG), Africa \& Madagascar Department et Institut de Systématique, Évolution et Biodiversité, Muséum National d'Histoire, Naturelle, 57 rue Cuvier, 75231, Paris, France.

4 Missouri Botanical Garden, Madagascar Research and Conservation Program, BP 3391-Anjohy, 101, Antananarivo, Madagascar.

561 rue du Lieutenant Ricard, Chatou, France.

${ }^{6}$ Bas du Ruisseau, 97414, lle de la Réunion, France. 